\title{
In situ evidence for pre-capture qualitative selection in the tropical bivalve Lithophaga simplex
}

\author{
Gitai Yahel $^{1,4, *}$, Dominique Marie ${ }^{2}$, Peter G. Beninger ${ }^{3}$, Shiri Eckstein ${ }^{1}$, Amatzia Genin ${ }^{1}$ \\ ${ }^{1}$ The Interuniversity Institute for Marine Sciences of Eilat and the Department of Evolution, Systematics and Ecology, \\ The Hebrew University of Jerusalem, PO Box 469, Eilat 88103, Israel \\ ${ }^{2}$ Station Biologique de Roscoff, UMR7144, CNRS et Université Pierre et Marie Curie, Place G. Teissier, 29682 Roscoff, France \\ ${ }^{3}$ ISOMer-Laboratoire de Biologie Marine, Faculté des Sciences-Université de Nantes, 2 Chemin de la Houssinière, \\ 44322 Nantes Cedex 03, France
}

${ }^{4}$ Present address: The School of Marine Sciences and Marine Environment, Ruppin Academic Center, Michmoret 40297, Israel

\begin{abstract}
Few feeding studies have been performed on tropical bivalves, and in situ feeding studies are lacking altogether. We investigated retention efficiencies for natural particles in the coralboring tropical mytilid Lithophaga simplex. Using the in situ InEx technique (Yahel et al. 2005; Limnol Oceanogr Methods 3:46-58) SCUBA divers collected samples from the water inhaled and exhaled by undisturbed bivalves at the coral reef of Eilat (Gulf of Aqaba). Particle retention efficiencies were determined using flow cytometry analysis of the paired water samples. The photosynthetic bacterium Synechococcus $(0.9 \pm 0.1 \mu \mathrm{m})$ and larger eukaryotic algae (1 to $10 \mu \mathrm{m})$ were preferentially retained by the bivalve with removal efficiencies of up to $90 \%$ (1996 to 2000: averages of $69 \pm 14 \%$ and $60 \pm 17 \%$, respectively, $\mathrm{n}=74$ individual bivalves). The minute photosynthetic bacterium Prochlorococcus $(0.4 \pm 0.1 \mu \mathrm{m})$ was also moderately retained $(41 \pm 19 \%)$. Only a small proportion of the non-photosynthetic bacteria $(0.3 \pm 0.1 \mu \mathrm{m})$ were retained $(5 \pm 18 \%$, median of $9 \%)$, despite their numerical dominance in the plankton and considerable size overlap with Prochlorococcus. Sizeindependent preferential retention was also observed within particle types: (1) L simplex more efficiently retained Prochlorococcus and picoeukaryotic algal cells with higher chlorophyll content and (2) the small fraction of non-photosynthetic bacteria retained did not differ in size, but had higher nucleic acid content (compared to the inhaled population) an indicator for viable and active bacteria. We conclude that particle retention is not strictly size-dependent in L. simplex, and probably involves other cell attributes such as cell surface properties and/or motility.
\end{abstract}

KEY WORDS: Suspension feeding $\cdot$ Nutrition $\cdot$ Selectivity $\cdot$ Coral reefs

\section{INTRODUCTION}

Selective feeding is an important mechanism by which animals optimize their diet, e.g. by maximizing their energy gain or avoiding harmful food (Krebs \& Davies 1997). The importance of selective feeding in structuring the pelagic microbial community is well documented (Pernthaler 2005), but much less is known about selection in benthic suspension feeders (see Yahel et al. 2006).

In the past $20 \mathrm{yr}$, bivalve suspension-feeding mechanisms have been vigorously investigated using a variety of relatively new approaches. Outcome-based techniques such as automated particle counting and flow cytometry have established the basic characteristics of suspension feeding, and provided important clues to underlying mechanisms. These have been investigated, in turn, using a variety of recently developed techniques to directly study various mechanism aspects (for reviews see Gosling 2003, Ward \& Shumway 2004, Beninger 2009, this issue). While the mechanisms of particle transport, ingestion volume regulation, and pseudofaeces transport and rejection are all now reasonably well known (Gosling 2003), 
some aspects of particle processing by bivalves are still poorly understood. Among these, particle selection is, to date, a particularly intractable field, since it involves thousands of microscopic particles simultaneously passing over complex, and often occluding, processing structures, and no mechanism of recognition has yet been identified. It has long been known that bivalves are capable of particle selection (Ward \& Shumway 2004). Direct observations have recently clarified the roles of the gills and the labial palps in particle selection in 3 of the 4 principal bivalve processing systems, and have established that the observed selection was effected post-capture (i.e. after the particles had been deviated from the through current onto the gill frontal surfaces: Beninger et al. 1997, 2004, 2007, Ward et al. 1998a, Cognie et al. 2003).

Our current knowledge of bivalve feeding is derived primarily from laboratory studies carried out with either laboratory-cultured algae or natural algal assemblages. It is yet unclear how valid the predictions and models based on laboratory experiments are to actual field situations; therefore, reliable methods are needed for in situ study of bivalve feeding (e.g. Cranford 1999, Cranford \& Hill 1999, Kotta \& Møhlenberg 2002, MacDonald \& Nodwell 2003). The recent development of the InEx technique has enabled in situ sampling of inhalant and exhalent currents from undisturbed suspension feeders (Yahel et al. 2003, 2005, 2007).

Another gap in our understanding of bivalve feeding is related to the fact that the species investigated have overwhelmingly come from temperate, eutrophic, or mesotrophic habitats (Newell \& Shumway 1993). These habitats are dominated by larger phytoplankton and characterized by relatively high loads of suspended sediments and large fluctuations of temperature and food availability. In contrast, few studies have investigated feeding characteristics and mechanisms in tropical suspension-feeding bivalves. Oligotrophic tropical waters are characterized by more stable conditions and are dominated by micron-size prokaryotic phytoplankton.

In the present study, we used the InEx sampling technique and subsequent flow cytometry analysis to quantify the in situ retention of naturally occurring phytoplankton and bacteria by the common tropical coral-boring mytild Lithophaga simplex.

\section{MATERIALS AND METHODS}

Study site. The study was carried out in the fore-reef ( 3 to $18 \mathrm{~m}$ depth) of the Eilat Coral Reef Nature Reserve, northern Gulf of Aqaba, Red Sea (Israel). For a description of the study site, see Genin et al. (2009) and references therein. The concentrations of chlorophyll (annual average: $~ 0.3 \mu \mathrm{g} \mathrm{l}^{-1}$; Genin et al. 2009) and particulate organic carbon $\left(\sim 0.1 \mathrm{mg} \mathrm{l}^{-1}\right.$; Yahel et al. 2003) are low. The phytoplankton community in the Gulf of Aqaba is dominated by ultraphytoplankton (<8 um; Yahel et al. 1998, Sommer et al. 2002). Small eukaryotic algae $(0.6$ to $4.0 \mu \mathrm{m})$ dominate during the winter mixing, whereas the cyanobacterium Synechococcus (0.9 to $1.2 \mu \mathrm{m}$; Sommer et al. 2002) dominates during spring blooms and is present at high concentrations $\left(>10^{4} \mathrm{ml}^{-1}\right)$ throughout the year. Prochlorococcus $(0.5$ to $0.7 \mu \mathrm{m})$ is absent during the winter and dominates (numerically) the phytoplankton assemblage during the warm season, when the water is stratified and nutrient-depleted (Lindell \& Post 1995). A thick (1 to $3 \mathrm{~m}$ ) phytoplankton-depleted layer is usually found over the reef (Yahel et al. 1998), due to intense grazing by a rich guild of benthic phytoplanktivores, mainly soft corals, sponges, ascidians and boring bivalves (Yahel et al. 1998, Genin et al. 2009).

Lithophaga simplex. The Lithophaginae (Bivalvia: Mytilidae) are important borers of a wide variety of calcareous substrata, including dead and live coral skeletons. In the Red Sea, the mussel L. simplex Iredale, 1939 (Fig. 1) inhabits the massive coral Astreopora myriophthalma (Lamarck, 1816) (Fig. 1) and, less frequently Goniastrea pectinata (Mokady et al. 1992), but is specific to other corals in other localities (Morton 1983). The bivalve reaches a few centimetres in length and is completely enclosed by the coral skeleton (Fig. 1A), with only the distal end of the siphons (1 to $3 \mathrm{~mm}$ in diameter) extending into the surrounding seawater (Fig. 1B). As a mytilid, it probably possesses a homorhabdic filibranch gill structure (i.e. all filaments are of 1 simple tubular type, and the gill is not capable of post-capture qualitative selection), but we are not aware of any histological studies of the gill structure for this species. A. myriophthalma forms large colonies (up to several metres), often carrying dense populations of L. simplex. In the Gulf of Aqaba, several hundred L. simplex specimens may colonize a single coral head, with a mean density of $22 \pm 11$ mussels $100 \mathrm{~cm}^{-2}$ of coral surface (Mokady et al. 1998). The overall density of $L$. simplex at the study site was 2.5 ind. $\mathrm{m}^{-2}$, about one-quarter of the overall Lithophaga spp. individuals we surveyed (Genin et al. 2009). The known benefits for the bivalves from this association include protection against predators and possibly the nutritional use of coral mucus (Shafir \& Loya 1983). While boring bivalves are commonly regarded as parasites, L. simplex was shown to provide ammonium from its nitrogenous waste to the photosynthetic symbiotic algae of its coral host (Mokady et al. 1998).

Water sampling. An in situ, unintrusive technique, based on the simultaneous pairwise collection of the water inhaled and exhaled by the animal (InEx), was 

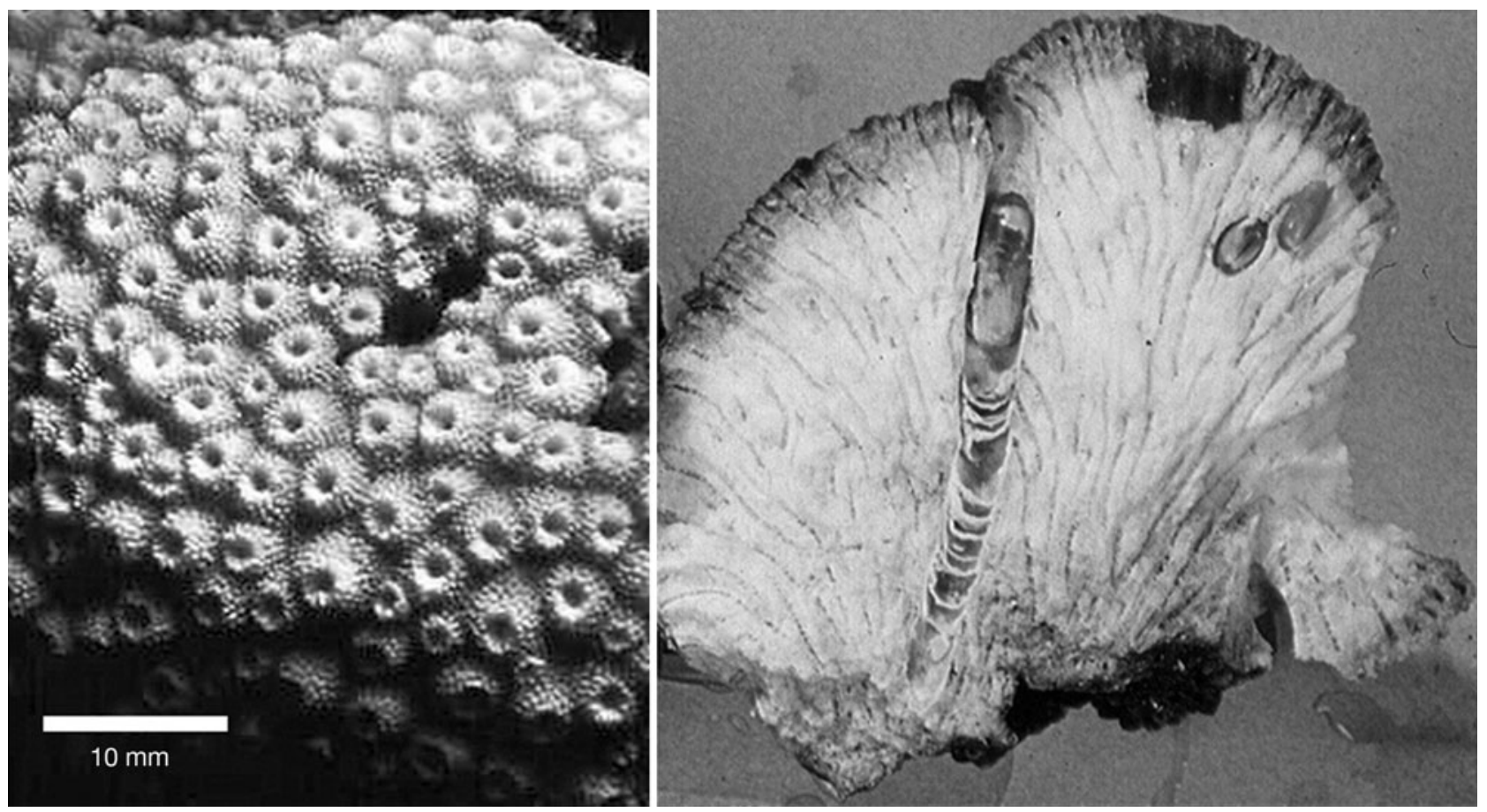

Fig. 1. (A) Lithophaga simplex inside the massive hermatypic coral Astreopora myriophthalma, as viewed from the outside (siphon diameter: ca. 2 to $3 \mathrm{~mm}$ ). (B) The boring bivalve L. simplex inside its host A. myriophthalma. Photographs courtesy of I. Brikner and Y. Loya

used to directly measure the rate and efficiency of particle removal from the water filtered by the studied animals as detailed in Yahel et al. (2005). Briefly, a SCUBA diver sampled the inhaled water by slowly $\left(\sim 0.5 \mathrm{ml} \mathrm{s}^{-1}\right)$ withdrawing water into a modified plastic pipette, attached at its proximal end to a syringe, while holding its open (intake) end ( 3 to $5 \mathrm{~mm}$ ) next to the bivalve inhalant siphon. A sample of exhaled water was taken simultaneously using an identical tube held within the exhalent jet, with the tube's intake end positioned $<2 \mathrm{~mm}$ above the bivalve exhalant siphon, using the excurrent jet to flush and then fill the tube. We used 2, 3 and $7 \mathrm{ml}$ samplers (LPt1, Pt5 and Pt10, respectively; in Yahel et al. 2005). Care was taken to avoid physical contact with the bivalve, and, when such contact occurred accidentally, the sample was aborted. Filling time (1 to $6 \mathrm{~min}$, depending on the sampler volume) was determined individually for each pair so that it would last $150 \%$ of the time it took the exhalant jet to flush clear an identical tube pre-filled with fluorescein dye (measured a few minutes prior to each sampling). Sampling duration was $>50$ times longer than the few seconds it took the water to pass through the bivalve. Thus, each 'InEx' pair represented a several-minute integration of bivalve activity. The difference in particle concentration in the 2 samples provides a measure of the retention efficien- cies of different particle sizes and types (Yahel et al. 2005).

The present study focused on the boring bivalve Lithophaga simplex living in Astreopora myriophthalma corals. Overall 74 pairs of InEx samples were collected from $L$. simplex in 16 dives during 10 sampling sessions spanning October 1996 to September 2000 and covering all 4 seasons.

Flow cytometry. A FACSort flow cytometer (Becton Dickinson, 15 mW, 488 nm, air-cooled Argon-ion laser) was used to measure the concentration and cell characteristics of non-photosynthetic microbes (hereafter referred to as non-photosynthetic bacteria [Bact]) and the 3 dominant autotrophic groups in the reef waters (Prochlorococcus [Pro], Synechococcus [Syn] and picoeukaryotes [Euk]). Taxonomic discrimination was made based on the orange fluorescence (Fl2) of phycoerythrin and the red fluorescence (Fl3) of chlorophyll (Marie et al. 1999), and on side scatter (SSC, a proxy of cell volume; Simon et al. 1994) and forward scatter (FSC, a proxy of cell size; Cunningham \& Buonnacorsi 1992, Robertson et al. 1998). Each sample was analyzed twice. First, 150 to $300 \mu$ of the sample water $\left(>2.5 \times 10^{4}\right.$ cells) was analyzed during 2 to $3 \mathrm{~min}$, for determination of ultra-phytoplankton with the discriminator set to Fl3. A second run was used to analyze cells with no autofluorescence, i.e. non-photosynthetic 
microbes. To visualize these cells, a $250 \mu$ l volume of the sample water was incubated with the nucleic acid stain SYBR Green I (20 min dark incubation at room temperature, $1: 10^{4}$ of SYBR Green commercial stock) (Marie et al. 1999). About $50 \mu$ l of sample water $(>4 \times$ $10^{4}$ cells) was analyzed during a 2 min run with a low flow rate, and the discriminator was set to green fluorescence (Fl1). Prochlorococcus has very weak chlorophyll fluorescence near the surface, especially in summer. Thus, in some cases, when full separation from the noise was not possible, it was necessary to apply a Gaussian fit to a density distribution plot of the SSC or Fl3; this extrapolation allows better estimates of Prochlorococcus cell concentration. Only samples where the non-photosynthetic bacteria and Prochlorococcus populations could be fully resolved, from the noise and from each other, were used for subsequent analysis of cell population attributes.

Yellow-green beads (Polysciences; diameter: $1 \mu \mathrm{m}$ ) were used as an internal standard in each sample, and (unless stated otherwise in the text) all cellular attributes were normalized to the beads using the equation:

$$
\overline{\text { Norm }}_{i, j}=\frac{\overline{\text { Population }}_{i, j}}{\overline{\text { Beads }}_{i, j}}
$$

where $\operatorname{Norm}_{i, j}$ is the normalized mean cell population $i$ (e.g. Synechococcus) for the mean cell attribute $j$ (e.g. SSC) (Marie et al. 1999). This normalization allows proper comparison of results obtained using different instrument settings.

The comparisons of cell properties were especially robust due to the paired sampling design applied in the present study (the same populations were compared in the same water prior to and after passage through the bivalve). The normalization to the calibration beads provided additional protection against instrumental drifts and shifts in sheath fluid properties.

Raw (list mode) data were recorded using 4 decades $\left(10^{0}\right.$ to $\left.10^{4}\right) \log$ scale and 256 bins (channels) and analyzed using Cytowin (Version 4.1 developed by D. Vaulot, www.sb-roscoff.fr/Phyto/cyto.html\#cytowin) or WinMDI (Version 2.8 developed by J. Trotter, http:// facs.scripps.edu/software.html).

FSC is correlated to the size and the equivalent sphere diameter (ESD) of particles. Because these relationships are roughly linear for up to $\sim 5 \mu \mathrm{m}$ particles (Cunningham \& Buonnacorsi 1992, Robertson et al. 1998, Cavender-Bares et al. 2001), FSC is widely used as a relative or absolute measure of size (Grob et al. 2007). For simplicity we report the ratio of FSC of particles to the FSC of $1 \mu \mathrm{m}$ beads as cell size in micrometre units. Since we neither measured the cells microscopically, nor calibrated our flow cytometer measurements (Cavender-Bares et al. 2001, Shalapyonok et al. 2001, Grob et al. 2007), the sizes given here should be regarded as approximations, especially for larger particles $(>8 \mu \mathrm{m})$ at the limits of the dynamic range used. Due to this limitation the flow cytometer counts were not transformed to cell biomass.

Log to linear transformation was done using the equation $x_{\operatorname{lin}}=10^{4 x_{\log ^{2}} 256^{-1}}$. No normalization to beads was applied to the density distribution examples presented below; thus, care was taken to average and compare only a few (>12) samples from adjacent water samples, which were run consecutively using exactly the same instrument settings.

Discrimination of the 4 particle types was not on the same taxonomic level. Moreover, the accuracy of discrimination was also variable; it was close to $100 \%$ for Synechococcus and the eukaryotic algae, but much lower for Prochlorococcus and non-photosynthetic bacteria that, on occasion, merged with the noise. To be conservative, we have omitted from the cell property analysis any samples in which the non-photosynthetic bacteria, Prochlorococcus, and noise could not be fully resolved. As a result, we have most likely overestimated the actual differences between the nonphotosynthetic bacteria and Prochlorococcus populations. Population size has an important effect on the accuracy of statistical description of cell properties. Thus, larger confidence intervals were usually associated with smaller populations such as the eukaryotic algae (and in some seasons also Prochlorococcus), as well as with the reduced populations in the exhaled water.

Eventual differences in retention of live versus dead bacteria were investigated using the redox dye 5-cyano2,3-ditolyl tetrazolium chloride (CTC) staining technique (Sieracki et al. 1999) for the InEx experiments undertaken in September 2000. An aliquot taken from each water sample was incubated in the dark, at room temperature, with $2 \mathrm{mmol} \mathrm{l}^{-1} \mathrm{CTC}$ (Polysciences). Incubation was terminated after $15 \mathrm{~min}$ by the addition of $0.1 \%$ glutaraldehyde. The sample was then analyzed in a third run. In a positive control, established by enriching sample water with $1 \%$ LB medium, the CTC positive cell concentration doubled within $20 \mathrm{~min}$.

Statistical analysis. The sampling design (InEx) was specifically developed as a 'pairwise comparison' (Yahel et al. 2005). Therefore, a 'within-subject' design (Rao 1997 , i.e. paired $t$-test, repeated-measure ANOVA, and their nonparametric alternatives) was used throughout the analysis to test the null hypothesis of unselective retention. Data are reported as averages $( \pm 1$ SD) unless stated otherwise. Statistical analyses were done using STATISTICA for Windows (Ver. 6.0, StatSoft).

Comparisons of cell size-frequency distributions were done within runs using samples stained with the nucleic acid stain SYBR Green I. Prochlorococcus was distinguished from the non-photosynthetic bacteria on the SSC versus red fluorescence cytogram based on their 
red chlorophyll fluorescence. Bin averages were calculated for cell frequencies within each of the 256 logarithmically spaced bins (channels) and normalized as the percentage of the total number of cells in the respective population.

In classical grazing experiments, suspension-feeder activity affects food concentrations in the experimental vessel (Chesson 1983, Riisgård 2001a). Measuring direct filtration efficiency, as was done here, allows estimation of the Chesson selectivity index $\left(\alpha_{\mathrm{i}}\right)$ as the maximum-likelihood estimator: $\alpha_{i}=F_{i}\left(\sum_{i=1}^{m} F_{i}\right)^{-1}$ (Case 1 in Chesson 1983), where $m$ is the number of particle types and $F_{i}$ is the filtration efficiency for the $i$ th particle type, calculated as: $F_{i}=\left(\operatorname{In}_{i}-\mathrm{Ex}_{i}\right) / \operatorname{In}_{i}$ (where $\operatorname{In}_{i}$ and $\mathrm{Ex}_{i}$ are the concentrations of the $i$ th particle type in the water inhaled and exhaled by the studied animal, respectively). A separate $\alpha_{i}$ was calculated for each paired water sample. For better visualization $\alpha_{i}$ were rescaled to $\varepsilon_{i}$ using the equation $\varepsilon_{i}=\left(m \alpha_{i}-1\right) /\left[(m-2) \alpha_{i}+1\right]$, where $m$ is the number of particle types available (Chesson 1983). Values of $\varepsilon_{i}$ range from -1 when none of the $i$ th type particles are taken, to 1 when the $i$ th type particles are the only ones retained. However, since the statistical properties of the $\varepsilon_{i}$ are not fully resolved, statistical inference was done solely with $\alpha_{i}$ values (Chesson 1983). To meet ANOVA requirements of homogeneity of variance and normality (verified by Cochran and Lilliefors tests, respectively), filtration efficiency was square-root and arcsine transformed, and Chesson $\alpha_{i}$ values were square-root transformed. Pairwise, post hoc comparisons of $\alpha_{i}$ values were made using the Tukey honestly significant differences (HSD) test for unequal $n$.

\section{RESULTS}

\section{Ambient conditions}

The water temperature at the study site ranged from 20 to $26^{\circ} \mathrm{C}$, with rare occurrences of warmer (up to $28^{\circ} \mathrm{C}$ ) days. The seasonal succession of phytoplankton was similar to that reported by Lindell \& Post (1995), characterized by concentration shifts of several orders of magnitude for Prochlorococcus (null to $2.5 \times 10^{5}$ cells $\left.\mathrm{ml}^{-1}\right)$ and eukaryotic algae $\left(10^{2}\right.$ to $\left.1.5 \times 10^{4} \mathrm{cells} \mathrm{ml}^{-1}\right)$. Synechococcus and the non-photosynthetic bacteria demonstrated much less variability, with changes between $10^{4}$ to $3 \times 10^{4}$ cells $\mathrm{ml}^{-1}$ for Synechococcus (except for a few days during the spring blooms) and $0.5 \times 10^{6}$ to $1 \times 10^{6}$ cells $\mathrm{ml}^{-1}$ for non-photosynthetic bacteria. The ambient concentration of CTC positive (active) bacteria in September 2000 was $6 \times 10^{4} \pm 3 \times$ $10^{4} \mathrm{ml}^{-1}(\mathrm{n}=32)$.

\section{Particle size and type}

Over the entire study period, the mean size of nonphotosynthetic bacteria populations in the ambient water averaged $0.3 \mu \mathrm{m}$ ( $\mathrm{n}=140$ flow cytometer runs) and those of the Prochlorococcus and Synechococcus were 0.4 and $0.9 \mu \mathrm{m}$, respectively. Eukaryotic algae were much larger with a mean FSC to $1 \mu \mathrm{m}$ beads ratio of $7.4 \pm$ 3.3. Within each water sample, the populations showed a wide size distribution, reflected by the large CVs of the population means (average: 262, 173 and 206\% for the non-photosynthetic bacteria, Prochlorococcus and Synechococcus, respectively). As a result, the size distributions of the Prochlorococcus population within each water sample had typically $>25 \%$ overlap with the nonphotosynthetic bacteria on the one hand (Fig. 2) and with the Synechococcus population on the other (Fig. 3). Similarly, the size of Synechococcus cells overlapped with both the Prochlorococcus from below and the eukaryotic algae from above, albeit to a lesser degree.

\section{Particle type retention}

Particle retention by Lithophaga simplex varied according to particle type (repeated-measure ANOVA, $F_{3,117}=254, \mathrm{p}<0.0001 ;$ Fig. 3). Synechococcus cells

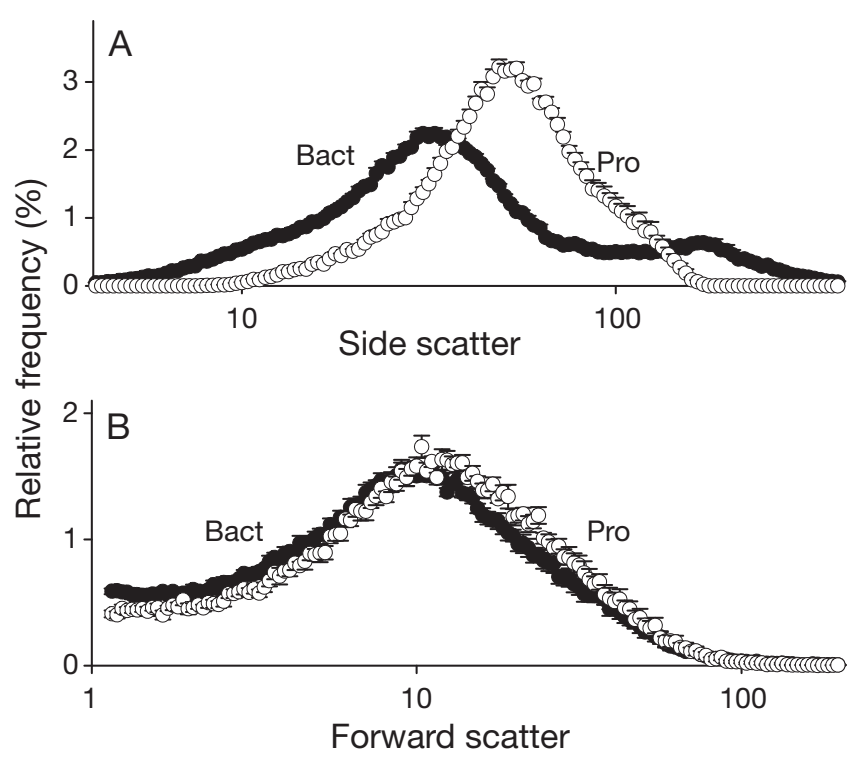

Fig. 2. Frequency distributions of the size and cellular properties of Prochlorococcus (Pro, ○) and non-photosynthetic bacteria $(B a c t, \bullet)$ in 10 representative samples collected in September 1998 from the ambient water next to the studied specimens. (A) Side scatter is related primarily to cell texture and volume of the cell. (B) Forward scatter is related to cell size. Horizontal axes are plotted using arbitrary, log-scale units. Error bars: $95 \%$ confidence intervals of the means. Note the large size overlap between the 2 bacterial populations 

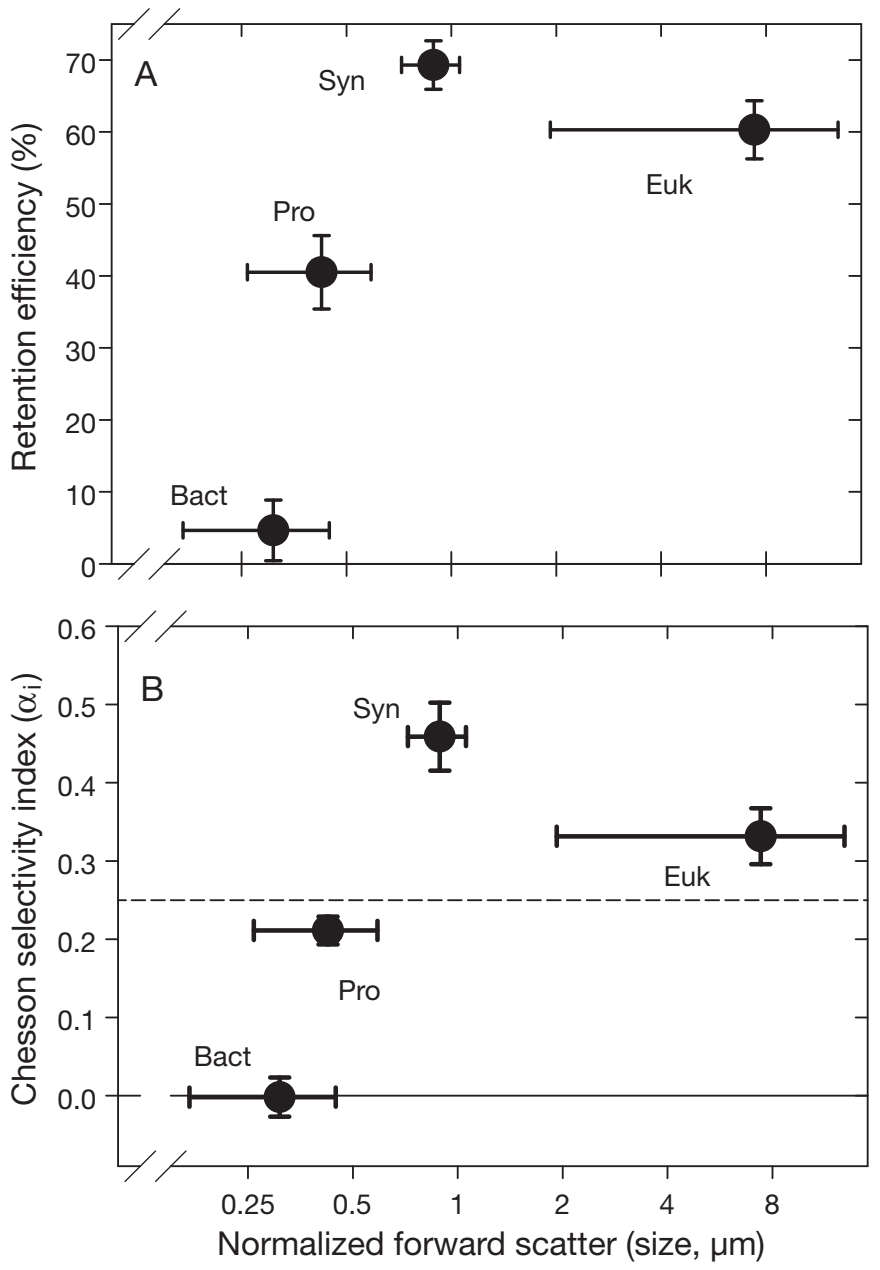

Fig. 3. Lithophaga simplex. (A) Average retention efficiency for each of the 4 particle types (Bact: non-photosynthetic bacteria; Euk: eukaryotic algae; Pro: Prochlorococcus; Syn: Synechococcus), plotted as a function of particle size. Vertical bars: $95 \%$ confidence intervals for mean retention efficiencies; horizontal bars: $90 \%$ prediction intervals for mean particle sizes. (B) Average selectivity index $\alpha_{i}$ (Chesson 1978) calculated for all InEx pairs when data for all 4 particle types were available. The expected value for non-selective feeding was 0.25 (dashed line). Vertical bars: $95 \%$ confidence intervals; horizontal bars: as in Panel A. Note the logarithmic scale of the $x$-axis

$(0.9 \pm 0.1 \mu \mathrm{m})$ were removed at efficiencies of up to $90 \%$ (average: $69 \pm 14 \%$; Fig. 3A). Larger eukaryotic algae (FSC: $7.4 \pm 3.3$ ) were removed with significantly reduced efficiency $(60 \pm 17 \%$, paired $t$-test, $\mathrm{p}<0.001)$, but comparison of selectivity indices indicated they were not significantly less preferred (Tukey HSD, p = 0.066). The minute photosynthetic bacterium Prochlorococcus $(0.4 \pm 0.1 \mu \mathrm{m})$ was also readily captured $(41 \pm$ $19 \%)$, but its removal efficiency was significantly lower (Tukey HSD, p $<0.001$ ) than that of the other 2 photosynthetic groups. Surprisingly, only a small proportion of the non-photosynthetic bacteria $(0.3 \pm$ $0.1 \mu \mathrm{m})$ were removed $(5 \pm 19 \%)$ despite the large size overlap between those bacteria and Prochlorococcus (Fig. 2B). When present, $>20 \%$ of the Prochlorococcus cells were removed in $88 \%$ of the InEx pairs (Fig. 4). In contrast, a removal of $>20 \%$ of non-photosynthetic bacteria was observed in only 7 of 74 cases, with zero removal in $25 \%$ of the cases (Fig. 4 ).

Despite the marked seasonal changes in particle abundance, the removal of photosynthetic particles remained nearly constant, resulting in a quasi-linear functional response (Fig. 5A-C), and the particle retention ranking did not change in the different sampling seasons (Fig. 5E). Seasonal variations in retention efficiencies were only evident for the eukaryotic algae (Kruskal-Wallis ANOVA, p < 0.05), but without a clear pattern. Despite the low retention efficiency of the non-photosynthetic bacteria, their removal was also correlated with ambient (inhaled) concentrations $\left(\mathrm{r}_{\mathrm{p}}=0.58, \mathrm{p}<0.001\right)$, indicating that removal occurred mostly in higher than average bacterial concentrations $\left(>5 \times 10^{5} \mathrm{ml}^{-1}\right.$; Fig. 5D).

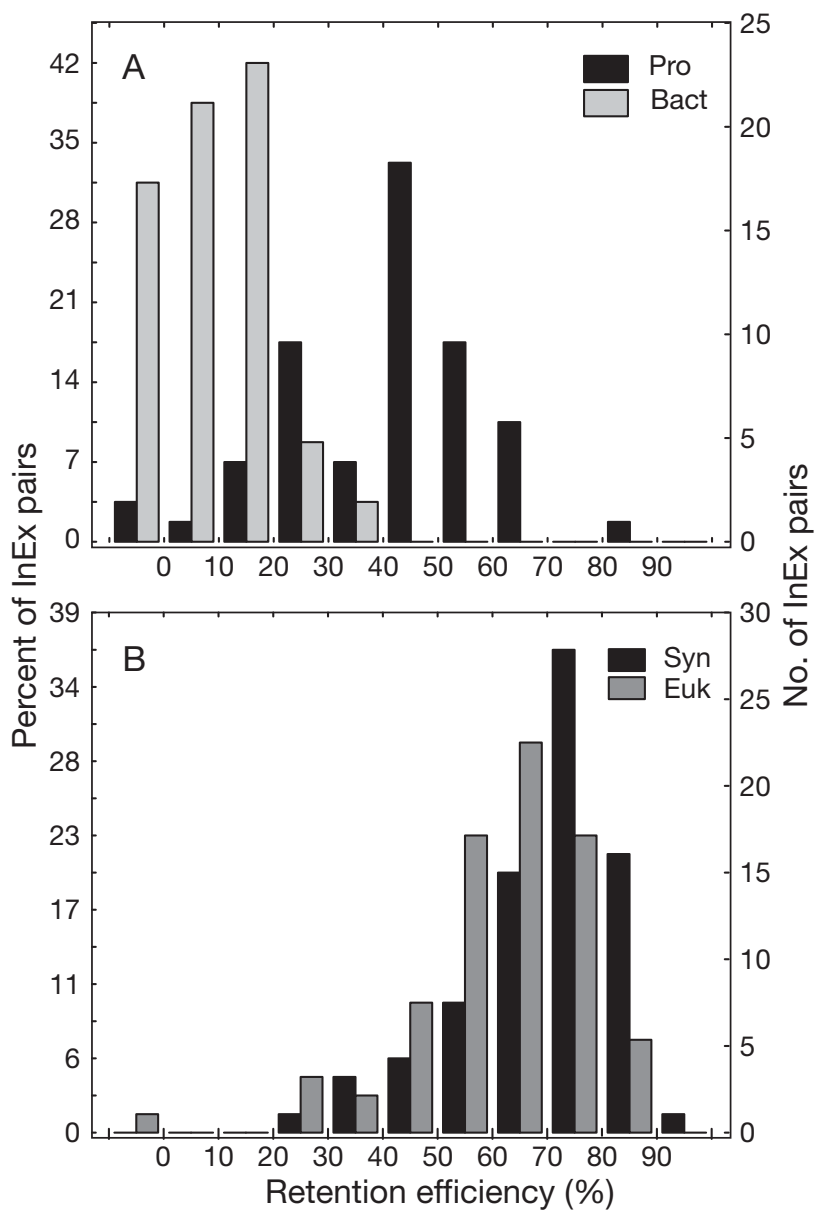

Fig. 4. Frequency of measured cell retention efficiencies for all 74 InEx pairs: (A) Prochlorococcus (Pro) and the nonphotosynthetic bacteria (Bact) and (B) Synechococcus (Syn) and eukaryotic algae (Euk) 


\section{Selective retention within particle types}

Selective retention was also observed within particle types. For example, within the Prochlorococcus and eukaryotic algae, cells with higher pigment content and higher SSC were always preferentially retained. Similarly, within the more homogeneous Synechococcus population such selectivity was observed at certain times of the year, notably the spring bloom of 1997 . Here Lithophaga simplex exhibited a clear preference
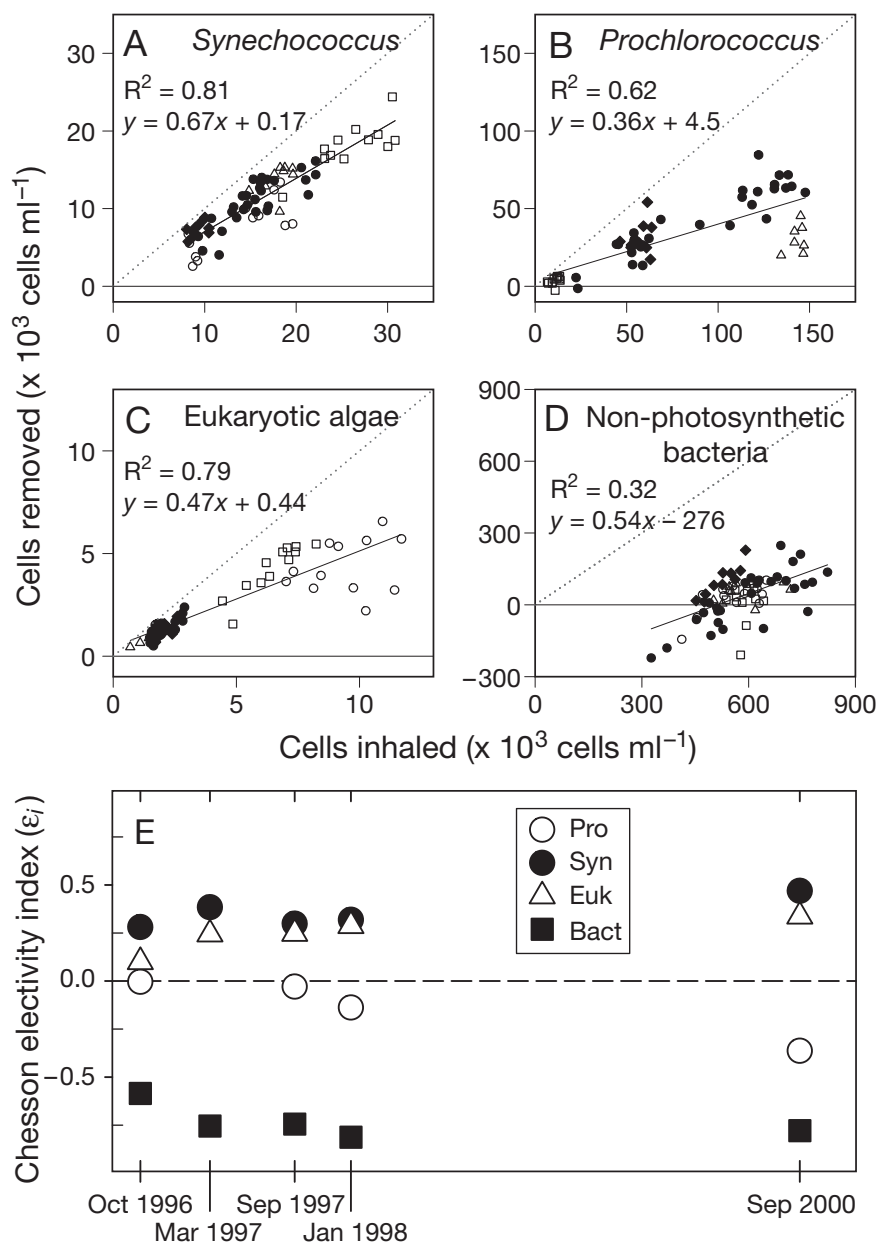

Fig. 5. Removal of each of the 4 ultra-planktonic particle types: (A) Synechococcus (Syn), (B) Prochlorococcus (Pro), (C) eukaryotic algae (Euk) and (D) non-photosynthetic bacteria (Bact), plotted against its ambient (inhaled) concentration. Dotted lines $(x=y)$ represent $100 \%$ removal. Different symbols denote different sampling periods. $\bullet$ : October 1996; O: March 1997; ๑: September 1997; $\square$ : January 1998; $\Delta$ : September 2000. Linear regression statistics are for all seasons pooled. (E) Particle preference in the different sampling periods. Chesson $\alpha_{i}$ values were rescaled to $\varepsilon_{i}$ so that they would be independent of the number of particle types available. $\varepsilon_{i}$ values range from -1 to 1 , where -1 indicates none of the $i$ th type particles are retained, and an $\varepsilon_{i}$ of 1 indicates cases when the $i$ th type particles are the only ones selected. Zero is the expected value for $\varepsilon$ if there is no selection. Error bars were omitted for clarity of presentation (Chesson 1983) for Synechococcus cells with higher fluorescence (proxy of pigments and nitrogen content) and stronger SSC (proxy of cell texture and pigment content). Fig. 6 shows an example of a shift to the left in the optical properties distribution of the cells that were not re-

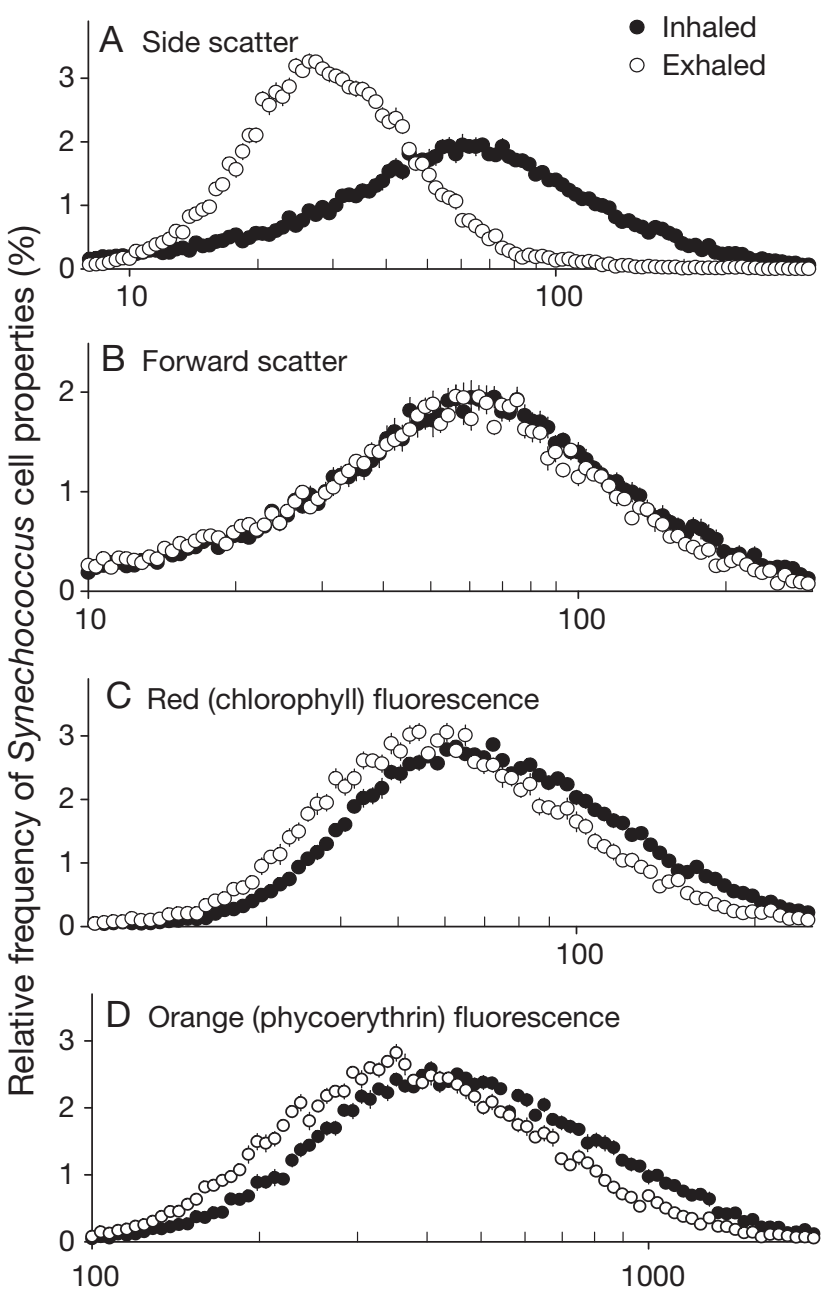

Fig. 6. An example of selective retention among a population of Synechococcus cells. The normalized frequency distributions of the optical cell properties (A to D) in the water inhaled (•) and exhaled (O) by 12 Lithophaga simplex were plotted. InEx samples were collected during $2 \mathrm{~d}$ in the 1997 eukaryote spring bloom (18 and 25 March 1997). As each sample was internally normalized, similar relative frequencies (y position) do not indicate similar concentrations (exhaled concentrations were considerably lower). List mode data were transformed from log to linear, and the skewness (Sk) and kurtosis $(\mathrm{Ku})$ were calculated separately for each sample before normalization. The difference in the location of the distribution (population mean) was highly significant in all cases (paired $t$-test, $\mathrm{p}<0.001$ ). The shapes of the distributions were also significantly different for all but the phycoerythrin fluorescence distribution (Wilcoxon matched pairs test, $\mathrm{p}<0.05$ for the comparison of both the Sk and $\mathrm{Ku}$ within each pair). Orange fluorescence is related to Synechococcus phycoerythrin content (a light-harvesting and nitrogenstorage pigment). Horizontal axes are plotted using arbitrary, logscaled units. Error bars: $95 \%$ confidence intervals of the means 


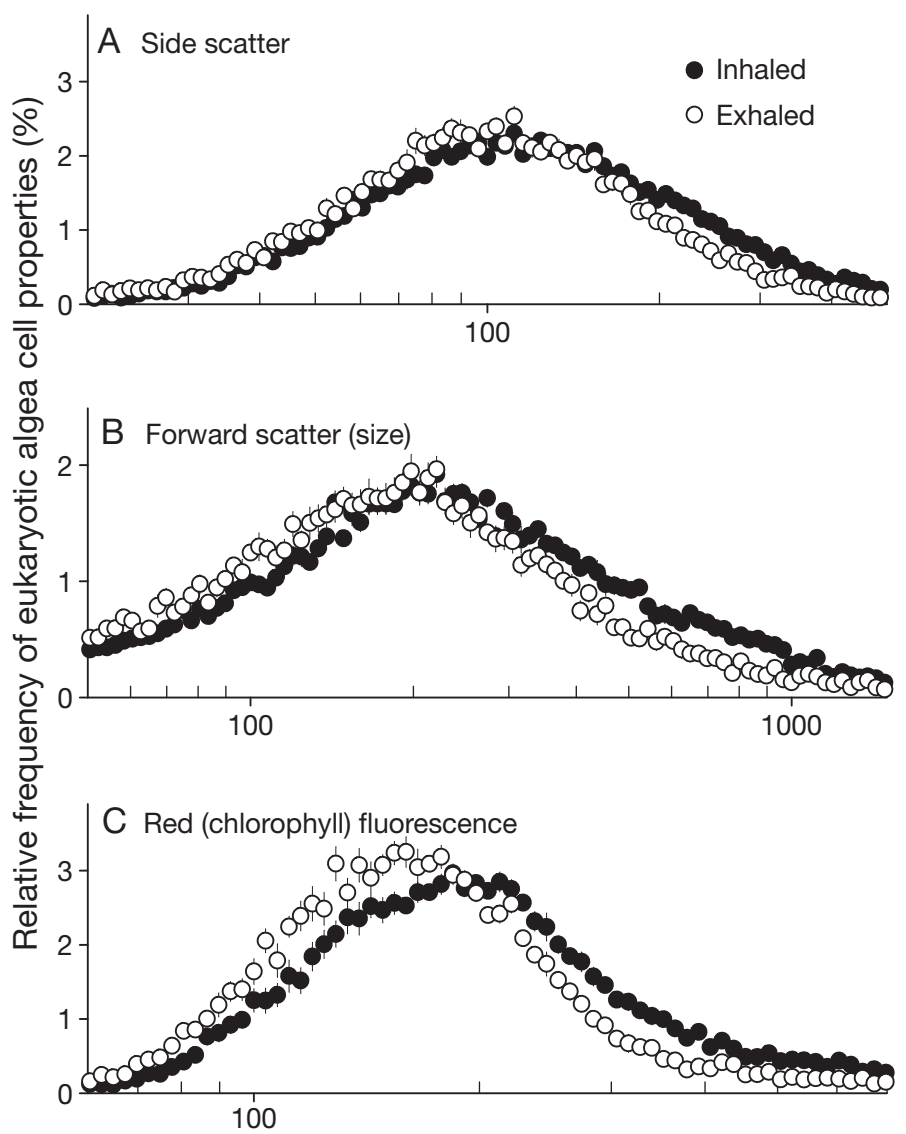

Fig. 7. As for Fig. 5A-C, but for eukaryotic algal (2 to $10 \mu \mathrm{m})$ cells. Since these cells normally do not contain phycoerythrin, the orange fluorescence signal was not plotted. The difference in the location of the distribution (population mean) was highly significant in all cases (paired $t$-test, $\mathrm{p}<0.001$ ). The shapes of the distributions were also significantly different for all but the side scatter distributions (Wilcoxon matched pairs test, $\mathrm{p}<0.05$ ) tained by 12 L. simplex specimens. Selection for larger Synechococcus cells (shift to the left in the cells' FSC, a proxy of cell size) is much more muted in this example, but was evident in other seasons. Cell distributions were always peaked $(\mathrm{Ku}>0)$, with a long right tail ( $\mathrm{Sk}>0)$ in both the inhaled and the exhaled waters, but the exhaled populations were significantly less skewed and less peaked (except for the red chlorophyll fluorescence). These results show that over and above the general preferential retention for Synechococcus, $L$. simplex preferentially retained higher quality Synechococcus. The same trend was also evident for the more diverse group of eukaryotic algae (Fig. 7).

The within-particle type preferences are summarized in Fig. 8, based on each of the cellular attributes recorded by the flow cytometer. Most notable is the preferential retention of cells with higher chlorophyll content within the populations of Prochlorococcus and eukaryotic algae (Wilcoxon matched pairs test, p < 0.001). Lithophaga simplex also preferentially retained larger Synechococcus and eukaryotic algae, whereas no such size preference was observed for the Prochlorococcus population. While L. simplex showed clear preference for Synechococcus cells with higher pigment content (e.g. Figs. 6 \& 7) during some seasons (spring and summer 1997, autumn 2000), this was not the case during the autumn of 1996 and winter of 1998.

Interestingly, the small fraction (5\%) of non-photosynthetic bacteria retained by Lithophaga simplex had significantly higher green fluorescence (nucleic acid content) in comparison to the nucleic acid content of the bacteria in the exhaled waters. A comparison between CTC positive and negative cells (Gasol et al. 1995) in 8 InEx pairs (September 2000) showed no significant difference (paired $t$-test, $\mathrm{p}>0.05$ ).

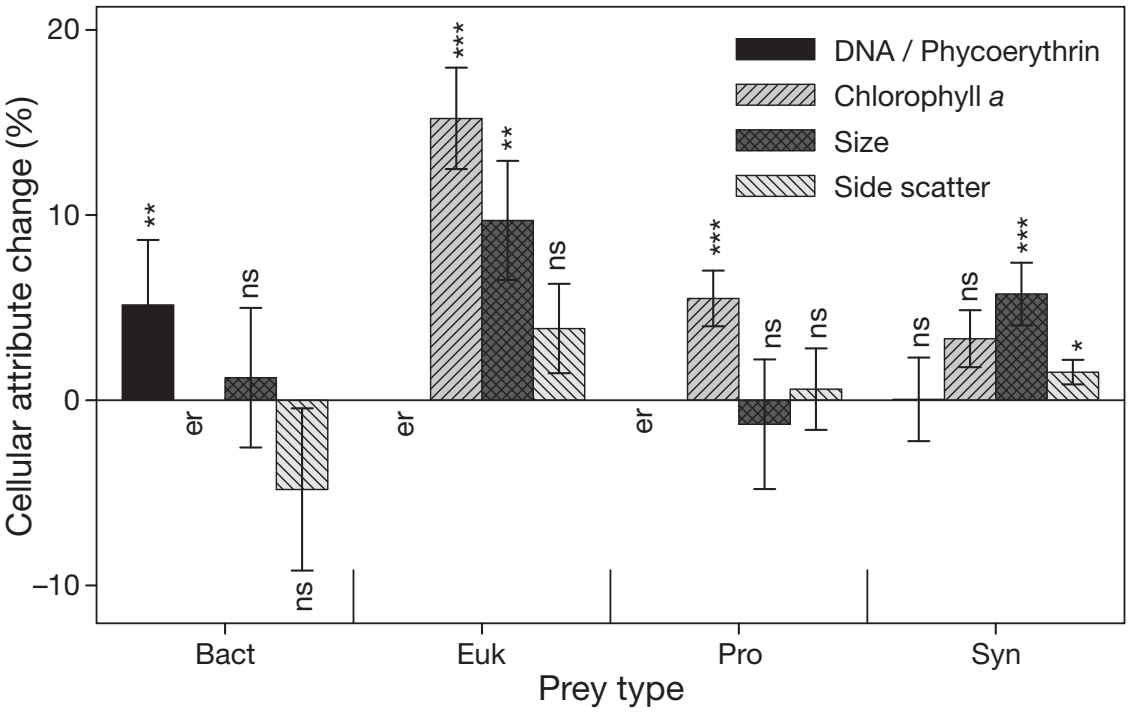

Fig. 8. Differences in cells' optical characteristics between inhaled and exhaled populations. Positive bars indicate positive selection for particles with higher cell attributes (fluorescence or scatter); negative bars indicate negative selection for the measured optical attribute of the cells. Each bar represents the average change calculated separately for each optical attribute in InEx pairs as: $100 \times\left(A_{\text {In }}-A_{\text {Ex }}\right) A_{\text {In }}{ }^{-1}$, where $A$ is the respective attribute. The significance of the difference between inhaled and exhaled population attributes was tested using Wilcoxon matched pairs test (ns: no significant difference; ${ }^{*} \mathrm{p}<0.05$; $\left.^{* *} \mathrm{p}<0.01 i^{* * *} \mathrm{p}<0.001\right)$. Attributes that were not relevant for the respective particle population are indicated as 'er'. Error bars: SE 


\section{DISCUSSION}

The present study demonstrates in situ the selective, size-independent capture of planktonic microorganisms by the tropical boring mytilid Lithophaga simplex. Use of the InEx technique ensured that only the first step in the feeding process was targeted, namely, particle capture and retention from the highly diluted medium in which these tropical bivalves reside. Such pre-capture qualitative selection is biologically interesting from several standpoints. (1) It has not yet been documented for any bivalve (but see Yahel et al. 2006 regarding sizeindependent selectivity in sponges). (2) It obviously raises the question of possible mechanisms. Mucus trapping of particles deflected onto the gill filament frontal surface has been assumed to be the norm for homorhabdic-gill bivalves (Silverman et al. 1999, Beninger et al. 2003, Beninger \& Decottignies 2008), but this is obviously incongruent with the results observed for $L$. simplex. (3) It is at variance with theoretical predictions of little or no selection under conditions of low particle concentration (Sierszen \& Frost 1992). Concerning the latter point, it may be argued that suspension feeders in oligotrophic habitats are adapted to a different scale of relative particle concentrations.

The pioneering studies by Møhlenberg \& Riisgård (1978), Palmer \& Williams (1980), Jørgensen et al. (1984) and Riisgård (1988) established that retention efficiencies by a variety of bivalves representing the main processing systems were size-dependant, with an asymptotic increase in retention efficiency with increasing size of the food particles. Such size-dependant asymptotic curves may be typical for many particle types, but there is persistent evidence of partially sizeindependent retention for certain particle types (Kiørboe \& Møhlenberg 1981; for review see also Ward \& Shumway 2004). Reports of size-independent retention are particularly intriguing (Newell et al. 1989, Bougrier et al. 1997), since capture and retention are thought to be purely mechanical or hydro-mechanical processes (Jørgensen 1981, Beninger et al. 1992, 2003, Nielsen et al. 1993, Silverman et al. 1996b, 1999, Ward et al. 1998b, Beninger \& Decottignies 2008, present paper).

To date, all studies reporting size-independent retention have used either cultured algae in laboratory experiments, or natural algal assemblages in laboratory experiments. Overwhelmingly, the majority of bivalve and algal species investigated have come from temperate, eutrophic, or mesotrophic habitats. Sizeindependent retention of phytoplankton has been reported for some bivalves feeding on $>2 \mu \mathrm{m}$ particles in temperate zones and conjectured to be due to differences in shape, flexibility, or motility (reviewed by Ward \& Shumway 2004). Ward \& MacDonald (1996) studied 2 sub-tropical bivalves in Bermuda (Arca zebra,
Arciidae and Pinctada imbricata, Pteriidae). In the laboratory, both species showed typical size-dependant, pre-ingestive feeding responses, with an asymptotic increase in retention efficiency with increasing size of the food particles. A. zebra, but not P. imbricata, demonstrated particle selection, rejecting (in the pseudofeces) material with significantly higher carbon and lower nitrogen concentrations, thereby increasing the quality of material ingested by approximately $31 \%$. Qualitative selection in the tropical pearl oyster P. margaritifera has also been inferred from gut content analysis (Loret et al. 2000); however, the techniques of both studies do not allow the distinction between pre- and post-capture selection.

The selective pattern observed for Lithophaga simplex, whereby pico-planktonic cells of similar size are retained in different efficiencies, argues for qualitative rather than mechanistic selection, presumably an adaption for enhancement of the quality of the retained particles. For example, the photosynthetic bacterium Prochlorococcus was efficiently removed (up to $88 \%$ ), whereas non-photosynthetic bacteria that were essentially of the same size and shape were retained in null to very low efficiencies. The majority (90 to $95 \%$ ) of the non-photosynthetic bacteria in the oligotrophic waters at our study site were CTC negative, indicating dead, inactive, starved, or growth-arrested cells (see Davidson et al. 2004 for a review and contrasting data). Such bacteria are less preferred by protozoan grazers (delGiorgio et al. 1996, Jürgens \& Matz 2002).

Retention efficiencies and Chesson selectivity indices were significantly different among all 4 prey taxa examined (non-photosynthetic bacteria, Prochlorococcus, Synechococcus and eukaryotic algae) despite the large overlap of the cell size distribution (typically $>25 \%$; Fig. 2, and compare Figs. 6B \& 7B).

Within each of the photosynthetic cell populations, there was a general pattern of preferential retention of cells with higher chlorophyll content. Similarly, the small fraction of non-photosynthetic bacteria that was retained by the bivalve had a significantly higher nucleic acid content, compared to the rejected bacteria. These selectivity patterns prevailed regardless of large seasonal shifts in the planktonic community composition and abundance. The most notable exception was the reduced retention efficiency of Prochlorococcus in September 2000 (Fig. 5B,E).

It should be noted that, while only a small portion of the non-photosynthetic bacteria was retained by Lithophaga simplex, other homorhabdic bivalves such as Geukensia demissa and Dreissena polymorpha efficiently retained such small cells (Kreeger \& Newell 1996, 2001, Silverman et al. 1996a). Nevertheless, assimilation of bacteria seems to be less efficient in comparison to phytoplankton (Kreeger \& Newell 1996, 
Nichols \& Garling 2000). Microscopic observation using nucleic acid staining (DAPI) reveals that, while most of the picoplankton was freely suspended (unattached), some bacteria were attached to aggregates, mucus, or marine snow (G. Yahel unpubl. data). It is therefore plausible that the small proportion of non-photosynthetic bacteria removed by L. simplex may have been ingested with such aggregates (Kach \& Ward 2008). Indeed, most of the bacteria removal occurred during spring blooms, when organic aggregates were prevalent in reef waters (G. Yahel pers. obs.).

Preference for cyanobacteria over diatoms (all $>3 \mu \mathrm{m})$ has been reported for several freshwater unionids (Baker \& Levinton 2000, 2003). However, in these cases, clear size differences existed between the different particle types, and selection was post-retention. The preferential retention of Synechococcus observed in the present study has also been observed in other coral reef suspension feeders examined using the InEx technique (Yahel et al. 2005, G. Yahel unpubl. data). The concentration of Synechococcus pigments was significantly reduced in comparison with other algal pigments in the water flowing over the reefs in Curacao, indicating its selective grazing (van Duyl et al. 2002). This contrasts with the situation observed for the pelagic habitat in the Gulf of Aqaba, where Synechococcus was shown to be the least-preferred cell type (Sommer et al. 2002). As the phytoplankton supply to the studied reef is mostly affected by pelagic processes (Genin et al. 2009), the seston available to reef benthic suspension feeders such as $L$. simplex may be impoverished of cells other than Synechococcus; thus, these benthic suspension feeders may have evolved to accept, or even select, these cyanobacteria.

Capture and retention of particles are generally considered to be purely mechanical or hydro-mechanical processes (Jørgensen 1981, Beninger et al. 1992, 2003, Nielsen et al. 1993, Silverman et al. 1996a,b, 1999, Ward et al. 1998b, Beninger \& Decottignies 2008). This view is at variance with the observations of sizeindependent retention reported here. There is at present no theoretical or practical framework for understanding differential retention of particles of similar sizes, shapes, flexibilities and densities. The most prominent shift between the inhaled and exhaled populations (Fig. 6) is observed in the SSC, which is generally associated with internal complexity and external cell surface traits. It is thus tempting to suggest that selection is made according to external cell characteristics that are revealed by differences in SSC. However, preference for higher pigment content (see also Fig. 8) suggests that other mechanisms such as chemosensory detection may also be at work (Beninger et al. 2008a). Shimeta (1993) and Shimeta \& Koehl (1997) suggested that the clearance of sub-micrometer par- ticles should be greatly enhanced by cell motility. Indeed, swimming behaviour has been reported in several cultured Synechococcus strains (Brahamsha 1999), and these are the particles that were most efficiently retained in the present study. Motility has not been documented for Prochlorococcus cells, which were much less efficiently retained in the present study. Differences in cell motility may thus be a factor in size-independent particle retention.

Another feature that might help account for sizeindependent particle retention is some form of particle recognition prior to capture. Such recognition has been reported post-capture in 2 marine bivalve species for the perifrustular envelope of diatoms (Beninger et al. $2004,2005,2008 a, b)$. This would be an interesting subject for future research on the mechanisms of precapture, size-independent particle retention.

If the preferential retention of Synechococcus is related to quality (e.g. Ward et al. 1997), it is of interest to determine what quality features may be discriminating. High-energy, low $\mathrm{N}$ and $\mathrm{P}$ coral mucus, rather than particles, was suggested as an important source of carbon for Lithophaga simplex (Shafir \& Loya 1983). If this is so, then we suggest that the pre-capture qualitative selectivity observed in $L$. simplex may not maximize carbon or energy gain, but rather other nutrients, as has been observed in some freshwater bivalves (Nichols \& Garling 2000) and oysters (Ward et al. 1997).

Acknowledgements. We thank R. Yahel, I. Ayalon, M. Ohevia, R. \& C. Wyeth, B. Munkes, Efrat Gotlibe, R. Motro, A. \& G. Brandes, Y. Shif, D. Tchernov and D. Weil for help in the field and laboratory; the IUI staff for logistic support; D. Lindell, A. Post, M. Kiflawi, E. Hadas and T. Katz for useful discussions; and the Rieger Foundation for supporting G.Y. The present study was funded by grants from the US-Israel Binational Science Foundations, The Israel Science Foundation and a grant from the German Ministry of Science, Technology and Education (BMBF) through the Red Sea Program. The flow cytometry analysis was funded by the French program PROSOPE and the European program PROMOLEC.

\section{LITERATURE CITED}

Baker SM, Levinton JS (2000) Feeding selectivity of native freshwater mussels (Unionidae) and competition with zebra mussels. J Shellfish Res 19:659

Baker SM, Levinton JS (2003) Selective feeding by three native North American freshwater mussels implies food competition with zebra mussels. Hydrobiologia 505:97-105

$>$ Beninger PG (2009) Introduction. Aquat Biol 6:175-180

Beninger PG, Decottignies P (2008) Worth a second look: gill structure in Hemipecten forbesianus (Adams \& Reeve, 1849) and taxonomic implications for the Pectinidae. J Molluscan Stud 74:137-142

> Beninger PG, Ward JE, MacDonald BA, Thompson RJ (1992) Gill function and particle transport in Placopecten magellanicus (Gmelin) (Mollusca: Bivalvia) as revealed using video endoscopy. Mar Biol 114:281-288 
Beninger PG, Lynn JW, Dietz TH, Silverman H (1997) Mucociliary transport in living tissue: the two-layer model confirmed in the mussel Mytilus edulis L. Biol Bull (Woods Hole) 193:4-7

Beninger PG, Dufour SC, Decottignies P, Le Pennec M (2003) Particle processing mechanisms in the archaic, perihydrothermal vent bivalve Bathypecten vulcani, inferred from cilia and mucocyte distributions on the gill. Mar Ecol Prog Ser 246:183-195

Beninger PG, Decottignies P, Rincé Y (2004) Localization of qualitative particle selection sites in the heterorhabdic filibranch Pecten maximus (Bivalvia: Pectinidae). Mar Ecol Prog Ser 275:163-173

> Beninger PG, Cannuel R, Jaunet S (2005) Particle processing on the gill plicae of the oyster Crassostrea gigas: fine-scale mucocyte distribution and functional correlates. Mar Ecol Prog Ser 295:191-199

Beninger PG, Decottignies P, Guiheneuf F, Barillé L, Rincé Y (2007) Comparison of particle processing by two introduced suspension feeders: selection in Crepidula fornicata and Crassostrea gigas. Mar Ecol Prog Ser 334:165-177

Beninger PG, Valdizan A, Cognie B, Guiheneuf F, Decottignies P (2008a) Wanted: alive and not dead: functioning diatom status is a quality cue for the suspension-feeder Crassostrea gigas. J Plankton Res 30:689-697

Beninger PG, Valdizan A, Decottignies P, Cognie B (2008b) Impact of seston characteristics on qualitative particle selection sites and efficiencies in the pseudolamellibranch bivalve Crassostrea gigas. J Exp Mar Biol Ecol 360:9-14

Bougrier S, Hawkins AJS, Heral M (1997) Preingestive selection of different microalgal mixtures in Crassostrea gigas and Mytilus edulis, analysed by flow cytometry. Aquaculture 150:123-134

Brahamsha B (1999) Non-flagellar swimming in marine Synechococcus. J Mol Microbiol Biotechnol 1:59-62

Cavender-Bares KK, Rinaldo A, Chisholm SW (2001) Microbial size spectra from natural and nutrient enriched ecosystems. Limnol Oceanogr 46:778-789

- Chesson J (1978) Measuring preference in selective predation. Ecology 59:211-215

> Chesson J (1983) The estimation and analysis of preference and its relationship to foraging models. Ecology 64: 1297-1304

Cognie B, Barillé L, Massé G, Beninger PG (2003) Selection and processing of large suspended algae in the oyster Crassostrea gigas. Mar Ecol Prog Ser 250:145-152

Cranford PJ (1999) Seasonal variation in food utilization by sea scallops and blue mussels. J Shellfish Res 18:299

Cranford PJ, Hill PS (1999) Seasonal variation in food utilization by the suspension-feeding bivalve molluscs Mytilus edulis and Placopecten magellanicus. Mar Ecol Prog Ser 190:223-239

- Cunningham A, Buonnacorsi GA (1992) Narrow-angle forward light-scattering from individual algal cells - implications for size and shape-discrimination in flow-cytometry. J Plankton Res 14:223-234

$>$ Davidson AT, Thomson PG, Westwood K, van den Enden R (2004) Estimation of bacterioplankton activity in Tasmanian coastal waters and between Tasmania and Antarctica using stains. Aquat Microb Ecol 37:33-45

del Giorgio PA, Gasol JM, Vaque D, Mura P, Agusti S, Duarte CM (1996) Bacterioplankton community structure: protists control net production and the proportion of active bacteria in a coastal marine community. Limnol Oceanogr 41: $1169-1179$

- Gasol JM, del Giorgio PA, Massana R, Duarte CM (1995) Active versus inactive bacteria: size-dependence in a coastal marine plankton community. Mar Ecol Prog Ser 128:91-97

Genin A, Monismith SG, Reidenbach MA, Yahel G, Koseff JR (2009) Intense benthic grazing of phytoplankton in a coral reef. Limnol Oceanogr 54:938-951

Gosling EM (2003) Bivalve molluscs-biology ecology, and culture. Fishing News Books, Blackwell, Oxford

Grob C, Ulloa O, Claustre H, Huot Y, Alarcon G, Marie D (2007) Contribution of picoplankton to the total particulate organic carbon concentration in the eastern South Pacific. Biogeosciences 4:836-852

Jørgensen CB (1981) A hydromechanical principle for particle retention in Mytilus edulis and other ciliary suspension feeders. Mar Biol 61:277-282

Jørgensen CB, Kiørboe T, Møhlenberg F, Riisgård HU (1984) Ciliary and mucus-net filter feeding, with special reference to fluid mechanical characteristics. Mar Ecol Prog Ser 15:283-292

Jürgens K, Matz C (2002) Predation as a shaping force for the phenotypic and genotypic composition of planktonic bacteria. Antonie Leeuwenhoek 81:413-434

Kach DJ, Ward JE (2008) The role of marine aggregates in the ingestion of picoplankton-size particles by suspensionfeeding molluscs. Mar Biol 153:797-805

$>$ Kiørboe T, Møhlenberg F (1981) Particle selection in suspension-feeding bivalves. Mar Ecol Prog Ser 5:291-296

Kotta J, Møhlenberg F (2002) Grazing impact of Mytilus edulis L. and Dreissena polymorpha (Pallas) in the Gulf of Riga, Baltic Sea estimated from biodeposition rates of algal pigments. Ann Zool Fenn 39:151-160

Krebs JR, Davies NB (1997) Behavioural ecology: an evolutionary approach, 4th edn. Wiley-Blackwell, Hoboken, NJ

Kreeger DA, Newell RIE (1996) Ingestion and assimilation of carbon from cellulolytic bacteria and heterotrophic flagellates by the mussels Geukensia demissa and Mytilus edulis (Bivalvia, Mollusca). Aquat Microb Ecol 11: 205-214

> Kreeger DA, Newell RIE (2001) Seasonal utilization of different seston carbon sources by the ribbed mussel, Geukensia demissa (Dillwyn) in a mid-Atlantic salt marsh. J Exp Mar Biol Ecol 260:71-91

Lindell D, Post AF (1995) Ultraphytoplankton succession is triggered by deep winter mixing in the Gulf of Aqaba (Eilat), Red Sea. Limnol Oceanogr 40:1130-1141

Loret P, Le Gall S, Dupuy C, Blanchot J and others (2000) Heterotrophic protists as a trophic link between picocyanobacteria and the pearl oyster Pinctada margaritifera in the Takapoto lagoon (Tuamotu Archipelago, French Polynesia). Aquat Microb Ecol 22:215-226

MacDonald BA, Nodwell LM (2003) A portable and practical method to monitor bivalve feeding activity in the field using time-lapse video technology. J Shellfish Res 22: 209-212

Marie D, Brussaard CPD, Partensky F, Vaulot D (1999) Flow cytometric analysis of phytoplankton, bacteria and viruses. In: Robinson JP (ed) Current protocols in cytometry. John Wiley \& Sons, New York, p 11.11.11-11.11.15

Møhlenberg F, Riisgård HU (1978) Efficiency of particle retention in 13 species of suspension feeding bivalves. Ophelia 17:239-246

> Mokady O, Arazi G, Bonar RB, Loya Y (1992) Settlement and metamorphosis specificity of Lithophaga simplex Iredale (Bivalvia, Mytilidae) in Red Sea corals. J Exp Mar Biol Ecol 162:243-251

> Mokady O, Loya Y, Lazar B (1998) Ammonium contribution from boring bivalves to their coral host-a mutualistic symbiosis? Mar Ecol Prog Ser 169:295-301 
Morton B (1983) Coral-associated bivalves of the Indo-Pacific. In: Russell-Hunter WD (ed) The Mollusca, ecology. Academic Press, Orlando, FL, p 140-224

Newell RC, Shumway SE (1993) Grazing of natural particulates by bivalve molluscs: a spatial and temporal perspective. Springer-Verlag, Heidelberg

Newell RC, Shumway SE, Cucci TL, Selvin R (1989) The effects of natural seston particle size and type on feeding rates, feeding selectivity and food resource availability for the mussel Mytilus edulis Linnaeus, 1758 at bottom culture sites in Maine. J Shellfish Res 8:187-196

Nichols SJ, Garling D (2000) Food-web dynamics and trophiclevel interactions in a multispecies community of freshwater unionids. Can J Zool 78:871-882

Nielsen NF, Larsen PS, Riisgård HU (1993) Fluid motion and particle retention in the gill of Mytilus edulis: video recordings and numerical modelling. Mar Biol 116:61-71

Palmer R, Williams L (1980) Effect of particle concentration on filtration efficiency of the bay scallop Argopeden irradians and the oyster Crassostrea virginica. Ophelia 19:163-174

Pernthaler J (2005) Predation on prokaryotes in the water column and its ecological implications. Nat Rev Microbiol 3:537-546

Rao PV (1997) Statistical research method in the life sciences. Duxbury Press, New York

Riisgård HU (1988) Efficiency of particle filtration and retention rate in 6 species of northeast American bivalves. Limnol Oceanogr 45:1192-1195

Riisgård HU (2001a) On measurement of filtration rates in bivalves - the stony road to reliable data: review and interpretation. Mar Ecol Prog Ser 211:275-291

Robertson BR, Button DK, Koch AL (1998) Determination of the biomasses of small bacteria at low concentrations in a mixture of species with forward light scatter measurements by flow cytometry. Appl Environ Microbiol 64: 3900-3909

Shafir A, Loya Y (1983) Consumption and assimilation of coral mucus by the burrowing mussel Lithophaga lessepsiana. In: Latif AFA, Bayoumi AR, Thompson MF (eds) Marine science in the Red Sea. Proc Int Conf Mar Sci Red Sea. Egyptian Academy of Scientific Research and Technology, Cairo, p 135-140

Shalapyonok A, Olson RJ, Shalapyonok LS (2001) Arabian Sea phytoplankton during southwest and northeast monsoons 1995: composition, size structure and biomass from individual cell properties measured by flow cytometry. Deep-Sea Res 48:1231-1261

Shimeta J (1993) Diffusional encounter of submicrometer particles and small cells by suspension feeders. Limnol Oceanogr 38:456-465

Shimeta J, Koehl MAR (1997) Mechanisms of particle selection by tentaculate suspension feeders during encounter, retention, and handling. J Exp Mar Biol Ecol 209:47-73

Sieracki ME, Cucci TL, Nicinski J (1999) Flow cytometric analysis of 5-cyano-2,3-ditolyl tetrazolium chloride activity of marine bacterioplankton in dilution cultures. Appl Environ Microbiol 65:2409-2417

Submitted: February 2, 2009; Accepted: May 26, 2009
Sierszen ME, Frost TM (1992) Selectivity in suspensionfeeders: food quality and the cost of being selective. Arch Hydrobiol 123:257-273

Silverman H, Lynn JW, Achberger EC, Dietz TH (1996a) Gill structure in zebra mussels: bacterial-sized particle filtration. Am Zool 36:373-384

Silverman H, Lynn JW, Dietz TH (1996b) Particle capture by the gills of Dreissena polymorpha: structure and function of latero-frontal cirri. Biol Bull 191:42-54

Silverman H, Lynn JW, Beninger PG, Dietz TH (1999) The role of latero-frontal cirri in particle capture by the gills of Mytilus edulis. Biol Bull (Woods Hole) 197:368-376

Simon N, Barlow RG, Marie D, Partensky F, Vaulot D (1994) Characterization of oceanic photosynthetic picoeukaryotes by flow cytometry. J Phycol 30:922-935

Sommer U, Berninger UG, Böttger-Schnack R, Cornils A and others (2002) Grazing during early spring in the Gulf of Aqaba and the northern Red Sea. Mar Ecol Prog Ser 239: 251-261

van Duyl FC, Gast GJ, Steinhoff W, Kloff S, Veldhuis MJW, Bak RPM (2002) Factors influencing the short-term variation in phytoplankton composition and biomass in coral reef waters. Coral Reefs 21:293-306

Ward JE, MacDonald BA (1996) Pre-ingestive feeding behaviors of two sub-tropical bivalves (Pinctada imbricata and Arca zebra): responses to an acute increase in suspended sediment concentration. Bull Mar Sci 59:417-432

Ward JE, Shumway SE (2004) Separating the grain from the chaff: particle selection in suspension- and deposit-feeding bivalves. J Exp Mar Biol Ecol 300:83-130

> Ward JE, Levinton JS, Shumway SE, Cucci T (1997) Site of particle selection in a bivalve mollusc. Nature 390:131-132

Ward JE, Levinton JS, Shumway SE, Cucci T (1998a) Particle sorting in bivalves: in vivo determination of the pallial organs of selection. Mar Biol 131:283-292

Ward JE, Sanford LP, Newell RIE, MacDonald BA (1998b) A new explanation of particle capture in suspension-feeding bivalve molluscs. Limnol Oceanogr 43:741-752

Yahel G, Post AF, Fabricius K, Marie D, Vaulot D, Genin A (1998) Phytoplankton distribution and grazing near coral reefs. Limnol Oceanogr 43:551-563

Yahel G, Sharp JH, Marie D, Hase C, Genin A (2003) In situ feeding and element removal in the symbiont-bearing sponge Theonella swinhoei: bulk DOC is the major source for carbon. Limnol Oceanogr 48:141-149

Yahel G, Marie D, Genin A (2005) InEx-a direct in situ method to measure filtration rates, nutrition, and metabolism of active suspension feeders. Limnol Oceanogr Methods 3:46-58

Yahel G, Eerkes-Medrano DI, Leys SP (2006) Size independent selective filtration of ultraplankton by hexactinellid glass sponges. Aquat Microb Ecol 45:181-194

Yahel G, Whitney F, Reiswig HM, Eerkes-Medrano DI, Leys SP (2007) In situ feeding and metabolism of glass sponges (Hexactinellida, Porifera) studied in a deep temperate fjord with a remotely operated submersible. Limnol Oceanogr 52:428-440

Proofs received from author(s): July 29, 2009 